\title{
セミコークス表面張力を用いたコークス強度への 石炭相性影響の評価
}

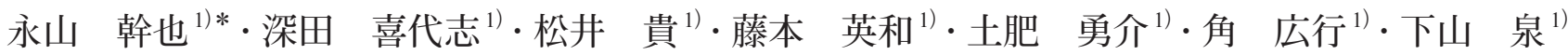

Evaluation of Coal Compatibility Effect in Coke Strength by Surface Tension of Semi-coke

Mikiya Nagayama, Kiyoshi Fukada, Takashi Matsui, Hidekazu Fujimoto, Yusuke Dohi, Hiroyuki Sumi and Izumi Shimoyama

Synopsis : Coal compatibility in coke strength is known as the effect that good combination of coals gives high strength coke and bad one gives the opposite in comparison with the strength expected from their average properties. To understand the phenomena of compatibility, we studied a correlation between adhesive strength and surface properties of semi-cokes obtained by heat treatment of coals at $500{ }^{\circ} \mathrm{C}$. As a result, we found that when the difference in surface tension between two semi-cokes was large, the strength of coke produced from the mixture of the two raw coals became low. The same tendency was also observed in laboratory scale carbonization tests and this effect was rationalized by high interfacial tension between two semi-cokes in the case that the difference in the surface tension was large, and accordingly, adhesive strength of the interface became low. To apply these findings to a multi-component coal blending technique used for commercial coke production, we proposed a new blending factor, the interfacial tension of a heat-treated coal blend which was derived from surface tensions of semicokes from coals in a coal blend, so that deterioration of coke strength was confirmed in commercial oven operation by increasing interfacial tension while other average properties of the blend were kept constant. This new technology enables us to evaluate more precisely the coal compatibility and to select the good combination of coals, which can contribute to the production of high strength coke and effective usage of coking coal resources.

Key words : cokemaking; blending technique; compatibility; blending factor; interaction; adhesive strength; coke strength; surface tension; interfacial tension; film flotation.

\section{1. 諸言}

石炭の相性は, コークスの製造において, これまで未解 決となっている課題である。この相性とは, 配合炭の平均 性状から推定されるコークス強度と, その配合炭を乾留し て得られたコークス強度との間にズレを生じさせる「配合 効果」として知られている。例えば, Fig.1 のように, 二種 類の石炭を配合した際，コークス強度がそれぞれの単味炭 より得られたコークスの強度の加重平均値より高位（良い 相性)，もしくは低位 (悪い相性）となることがある。

この石炭の相性について, Miyazu らは, 石炭の軟化溶融 温度域の重なりの影響を指摘して打り, 軟化溶融温度域の 重なりが大きいもの同士を組み合わせると，そのコークス 強度は単味炭のコークス強度の加重平均值よりも高くな り, 逆に, 軟化溶融温度域の重なりが小さいもの同士を配 合すると, そのコークス強度は加重平均値よりも小さくな ることを報告している ${ }^{1-3)}$ 。また，石炭の相性が起因する コークス強度への予期せ悪影響を最小限とするため, ビ
トリニットの平均最大反射率 $(\overline{\mathrm{R}} \mathrm{o})$ とギーセラー最高流動

度（MF）を適正範囲内に調整すること基本とした多銘柄で

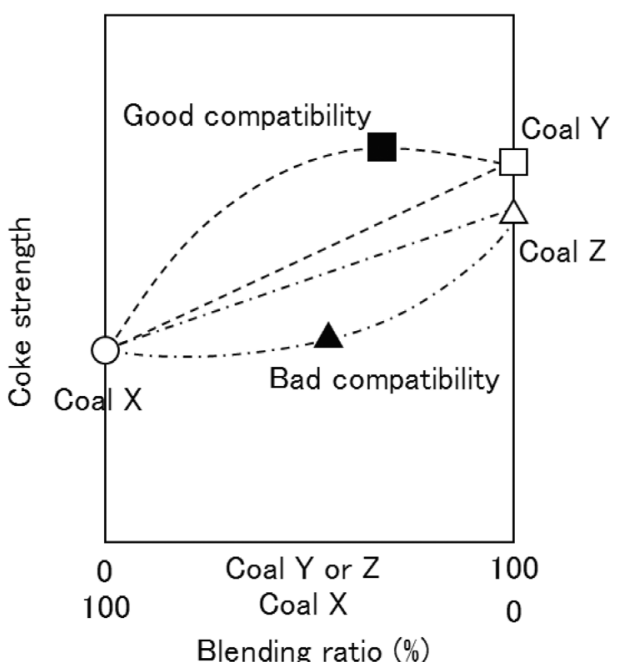

Fig. 1. Coal compatibility effect in two component coal blend.

原著論文：ISIJ Int., Vol.57 (2017), No.6, pp.989-995

平成 30 年3月 2 日受付 平成 30 年 4 月 18 日受理 (Received on Mar. 2, 2018 ; Accepted on Apr. 18, 2018 ; originally published in ISIJ Int., Vol.57, 2017, No.6, pp.989995)

1）JFEスチール (株) スチール研究所 (Steel Research Laboratory, JFE Steel Corporation, 1 Kokan-cho Fukuyama Hiroshima 721-8510)

* Corresponding author : E-mail : m-nagayama@jfe-steel.co.jp

DOI : http://dx.doi.org/10.2355/tetsutohagane.TETSU-2018-027 
の配合技術が開発されている4)。

さらに, Sakamoto らは膨張率や, 収縮率, 気孔率, 軟化 開始温度, 再固化温度, ビトリニット平均最大反射率, ギー セラー最高流動度などの石炭の性状から 2 銘柄間の石炭の 相性を推定するモデルを提案している5)。しかしながら， コークス操業に扎いて，特定の銘柄や組み合わせによっ て, 現在の配合技術では予期できないコークス強度の変化 があることは今でも知られている。筆者らは, これを石炭 の相性によるものであると考え, この相性が石炭粒子間の 接着に起因しているのではないかと考えた。

軟化溶融時の石炭粒子の結合については, 様々な研究が なされてきている。Nishiokaらは, 石炭軟化溶融時の2粒 子間の接着モデルを提案し, 粒子界面での接着よりも, 粒 子の発泡, 膨張による結合が重要であると報告している ${ }^{6)}$ 。 また, Aramakiらは，コークス基質の接着状態を観察する ことでその接着形態を「相溶接着」と「単純接着」の2種類 に分類し， $\Delta \mathrm{ST}$ (接着する2銘柄の固化温度の差）が小さ いことが良好な相溶接着を形成するために必要な条件であ ると報告している7)。しかし，上記のいずれの研究におい ても, 研究の主眼は接着よりも石炭の軟化溶融性（溶融特 性や固化特性）に置かれている。かつては接着の考えが含 まれた石炭粒子の結合モデルが提案されているにもかかわ らず ${ }^{8,9)}$, 近年では石炭の軟化溶融性に主眼を置いた研究が 主に行われている理由は, 石炭の流動性がコークス強度に 大きな影響を及ぼすことが広く知られるようになったこと に加えて, 石炭粒子の接着を評価する手法がそしいことも 影響していると推察される。しかしながら, 石炭の流動性 だけでは説明できない相性の影響を解明するためには，接 着結合に関する研究も不可欠であると筆者らは考えた。

筆者らは，接着結合は二つの石炭の粒子が互いにその界 面で接着して生成すると考えた。一般的な接着現象におい ては, 表面張力 (界面張力) が接着強度に影響を及ぼすこ とが知られている ${ }^{10)}$ 。しかしながら, 石炭粒子の接着が起 こるような高温で, 軟化溶融状態の石炭の表面張力を測定 する方法はなく, その表面張力を推定する方法も確立され ていない。

この課題を解決し, 石炭の相性と接着現象についての更 なる理解を深めるために, 石炭軟化溶融時の表面張力の評 価方法を開発し, 接着強度との関係を調査した。その結果, 接着強度は石炭の相性に対し，重要な役割を持っており， 熱処理した石炭 (セミコークス) の表面張力により, 石炭 の相性を評価可能であることを確認したことから, 本報に て報告する。

\section{2. 実験}

\section{$2 \cdot 1$ セミコークス表面張力の測定}

石炭は様々な分子構造の組織から構成されており, その
表面張力は分布を持つと考えられることから，セミコーク スの表面張力の測定方法として, 表面張力の分布を測定可 能である Film Flotation 法 ${ }^{11)}$ を採用した。具体的な方法は以 下である。

まず, $200 \mu \mathrm{m}$ 以下に粉砕した石炭 $2 \mathrm{~g}$ を内径 $20 \mathrm{~mm} \Phi$ の 坩堝内に嵩密度が $800 \mathrm{~kg} / \mathrm{m}^{3}$ となるように充填した。充填 後, 石炭を $500^{\circ} \mathrm{C}$ で昇温速度 $3^{\circ} \mathrm{C} / \mathrm{mim}$ で加熱した。得ら

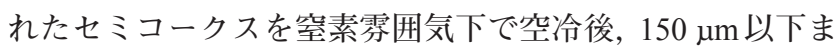
で粉砕した。表面張力の異なる溶液として，エタノールの 濃度を $0,4,8,10,13,16,20,25,30,37,50,75 \mathrm{wt} \%$ に 調整した 12 種類のエタノール水溶液を準備し, この表面 に前述のセミコークスを散布し, 水溶液表面に浮遊したセ ミコークス粒子の重量を測定した。この浮遊したセミコー クスの重量の, 散布したセミコークスの重量に対する割合 を算出した。12種類の濃度の異なるエタノール水溶液を用 いて測定した浮遊したセミコークスの比率と, エタノール 水溶液の表面張力から, セミコークスの表面張力分布を導 出した。なお, エタノール水溶液の表面張力が温度により 変化しないよう, 測定中の溶液の温度を $20^{\circ} \mathrm{C}$ 一定で管理し た。

\section{$2 \cdot 22$ 銘柄間の接着強度の評価}

石炭粒子間の接着強度を評価するためには多くの課題が ある。例えば，どのような種類の強度を測定すべきかが明 確でないこと, 石炭粒子間の界面を識別することが困難で あること, 更に, セミコークスの構造には石炭の軟化溶融 も影響を及ぼすこと, 粗大な欠陥が乾留時にしばしば生成 されてしまう事などが挙げられる。

これらの問題をすべて取り除くことは困難であるため, 強度評価時の悪影響を最小限に抑制することを目的とした 以下の方法を開発し, 強度の絶対值ではなく相対的な評価 をすることとした。具体的な方法は以下である。

まず，乾留時の気泡生成の影響を軽減するため, 2 銘柄 の石炭をそれぞれ75 $\mu \mathrm{m}$ 以下まで細かく粉砕した。この工 程は，粒子間の接触面積を増加させることも意困してい る。その後, 2 銘柄の石炭を配合率が $50 \mathrm{wt} \%$ ずつとなるよ うに配合した。この配合炭 $0.07 \mathrm{~g}$ を径 $6.7 \mathrm{~mm} \Phi$ の型枠に 装入し, $14 \mathrm{MPa}$ の荷重を 10 秒間かけ, 厚み $2.3 \mathrm{~mm}$ の錠剤 となるよう成型した。この錠剤を容器 $(\mathrm{W} 200 \mathrm{~mm} \times \mathrm{L} 200$ $\mathrm{mm} \times \mathrm{H} 70 \mathrm{~mm}$ ) の中で, $1 \mathrm{~mm}$ 以下に粒度調整した粉コー クス内に装入し, 窒素䨌囲気下で $1000^{\circ} \mathrm{C}$ まで昇温速度 $3{ }^{\circ} \mathrm{C} /$ $\min$ で乾留後, 窒素䨌囲気下で冷却し, サンプルを得た。万 能試験機（島津製作所製オートグラフ AG-I 50kN）を用い, サンプルの高さ方向に圧縮速度 $1 \mathrm{~mm} / \mathrm{min}$ で圧縮し, 破断 時の荷重を測定した。

測定された荷重を, サンプル直径の測定值より算出した 面積で除して求めた圧力を接着強度とし, 10 サンプルの平 均值とすることとした。なお, 圧縮方向を高さ方向とした のは, 圧縮時の亀裂の数を増やし, サンプル中の多くの粒 
子結合部分を破壊することで, 最弱欠陥の影響を小さくす るためである。

\section{$2 \cdot 3$ 試験炉での多銘柄乾留試験}

試験炉を用いた乾留試験は以下の方法で行った。まず, 複数銘柄の石炭をそれぞれ $3 \mathrm{~mm}$ 以下に粉砕した。この石 炭を所定の比率になるように配合し, 水分を $8 \mathrm{wt} \%$ に調整 した後, 容器 $($ W $273 \times$ L $260 \times$ H 300 mm) に嵩密度 750

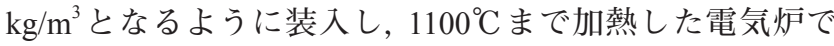
乾留した。冷却後, JIS K 2151 に準拠してドラム試験を実 施し，ドラム強度 $\mathrm{DI}_{15}^{150}$ を測定した。

\section{$2 \cdot 4$ 実炉での乾留試験}

実炉規模での乾留試験を福山 5 コークス炉 (窯数 : 220, 窯幅 : $0.43 \mathrm{~m} \times$ 炉高 : $6.50 \mathrm{~m} \times$ 炉長 : $15.43 \mathrm{~m}$ ) で行った。 試験期間中は装入炭の平均 $\bar{R} 0, \log M F$ 等の配合条件や操 業条件を，石炭の配合構成を除いて一定とした。

\section{3. 結果と考察}

\section{$3 \cdot 1$ セミコークスの表面張力}

Film Flotation 法により測定した, 石炭を熱処理して得ら れたセミコークスの表面張力の累積分布の一例を Fig.2に 示す。セミコークスの表面張力分布の值が, $30 \mathrm{mN} / \mathrm{m}$ から $60 \mathrm{mN} / \mathrm{m}$ の間に分布していることを確認した。

この累積分布より計算し，得られた頻度分布をFig.3に 示す。本研究では, 表面張力とコークス強度の関係を調査 するために, 表面張力の加重平均值を単味セミコークスの
表面張力として用いることとした。

\section{$3 \cdot 2$ コークス強度に及ぼす表面張力の影響評価}

\section{$3 \cdot 2 \cdot 1$ 接着強度への表面張力の影響}

2 銘柄間の接着強度に及ぼす表面張力の影響を明らか にするため，2銘柄の石炭より得られたコークスの接着 強度を評価した。セミコークス表面張力を含む石炭性状 を Table 1 に, 組み合わせた石炭の銘柄, 配合炭性状, 配合 した2銘柄のセミコークス表面張力差および接着強度を Table 2 に示す。なお，試験においては，単純接着界面にお ける表面張力が接着強度に及ぼす影響を明確に評価するた め，配合炭の $\log \mathrm{MF}$ は2.0 $\mathrm{log} / \mathrm{ddpm}$ 未満に調整した。

接着強度とセミコークス表面張力差, $\bar{R} 0$ そして $\log \mathrm{MF}$ の関係をそれぞれFig.4から6に示す。これらの結果より， 従来からの配合技術に打いてコークス強度を制御するため

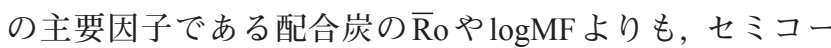
クスの表面張力が，接着強度との相関が高いことが確認さ

Table 1. Coal properties used in measurement of adhesive strength.

\begin{tabular}{ccccccc}
\hline $\begin{array}{c}\text { Coal } \\
\text { brand }\end{array}$ & $\begin{array}{c}\text { Surface tension } \\
(\mathrm{mN} / \mathrm{m})\end{array}$ & $\begin{array}{c}\bar{R} \mathrm{c} \\
(\%)\end{array}$ & $\begin{array}{c}\text { logMF } \\
(\log / \mathrm{ddpm})\end{array}$ & $\begin{array}{c}\text { TI } \\
(\%)\end{array}$ & $\begin{array}{c}\text { Ash } \\
(\text { wt\% d.b.) }\end{array}$ & $\begin{array}{c}\text { VM } \\
(\text { wt \% d.b. })\end{array}$ \\
\hline Coal A & 40.2 & 0.71 & 1.32 & 36.3 & 8.5 & 36.3 \\
Coal B & 37.8 & 1.62 & 1.28 & 22.2 & 9.7 & 17.3 \\
Coal C & 38.9 & 1.07 & 2.09 & 39.9 & 10.4 & 23.3 \\
Coal D & 40.9 & 0.72 & 2.11 & 18.1 & 8.6 & 37.3 \\
Coal E & 40.6 & 0.72 & 2.42 & 18.5 & 9.0 & 37.7 \\
Coal F & 39.6 & 1.00 & 2.43 & 39.2 & 8.0 & 28.1 \\
\hline
\end{tabular}

Table 2. Coal blending conditions for measuring adhesive strength.

\begin{tabular}{|c|c|c|c|c|c|c|}
\hline Sample & Sample1 & Sample2 & Sample3 & Sample4 & Sample5 & Sample6 \\
\hline \multirow{2}{*}{ Coal brand } & Coal A & Coal B & Coal B & Coal A & Coal B & Coal B \\
\hline & Coal B & Coal C & Coal D & Coal C & Coal E & Coal F \\
\hline$\overline{\mathrm{R}} \mathrm{o}(\%)$ & 1.17 & 1.35 & 1.17 & 0.89 & 1.17 & 1.31 \\
\hline $\log \mathrm{MF}(\log / \mathrm{ddpm})$ & 1.30 & 1.68 & 1.70 & 1.70 & 1.85 & 1.86 \\
\hline Difference of surface tension $(\mathrm{mN} / \mathrm{m})$ & 2.4 & 1.1 & 3.1 & 1.3 & 2.8 & 1.8 \\
\hline Adhesive strength (MPa) & 36.8 & 67.9 & 34.6 & 64.2 & 38.7 & 57.4 \\
\hline
\end{tabular}

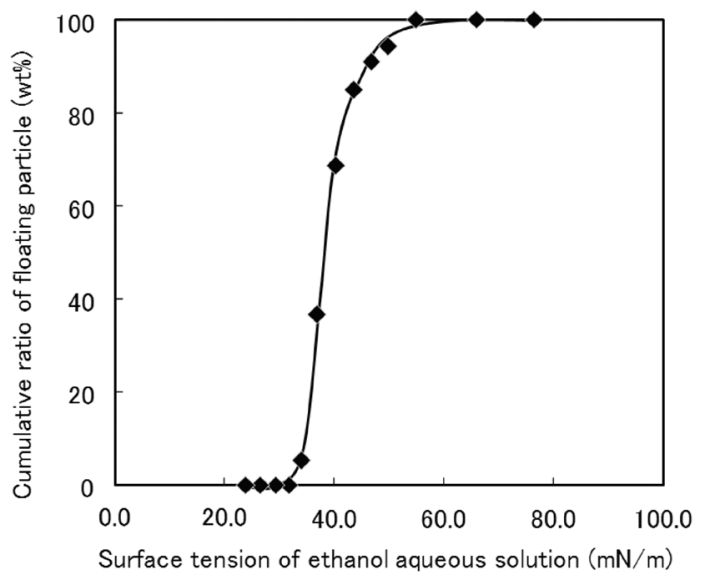

Fig. 2. Cumulative distribution of surface tension of semi-coke.

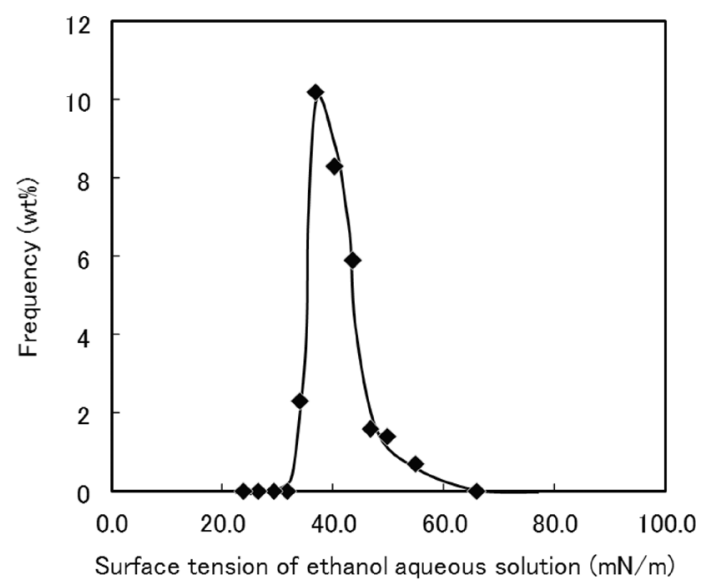

Fig. 3. Frequency distribution of surface tension of semi-coke. 
れた。一般的に，2物質間の表面張力差が大きいと，2物質 間の界面張力が大きくなり, その結果, 2物質間の接着強 度が弱くなることが知られている ${ }^{10)}$ 。本研究では軟化溶融 時の石炭の代替として冷却後のセミコークスの表面張力を 測定したが, 以上の結果から，この方法による表面張力の 測定は接着強度の推定に用いることができることがわかっ た。一方, 原炭の表面張力の測定を行い, 接着強度と原炭 の表面張力差の関係を調查したが明確な相関は確認できな かった (Fig.7)。この結果は, 接着強度を推定する上で, 原 炭ではなく, 熱処理したセミコークスを用いることが効果 的であることを表している。

表面張力が接着界面の構造に及ぼす影響を評価するた め, 銘柄間の基質界面の顕微鏡観察を行った。試験に用い た二層の錠剤サンプルの模式図を Fig.8に示す。まず，2銘 柄の石炭をそれぞれ $200 \mu \mathrm{m}$ 以下に粉砕後, サンプルの下層 になる石炭 $0.04 \mathrm{~g}$ を型枠の中に装入し, 荷重をかけた。そ の後, 上層となる石炭 $0.04 \mathrm{~g}$ 型枠内に加え, 再度荷重を かけることで峪密度を $1100 \mathrm{~kg} / \mathrm{m}^{3}$ に調整し，二層の錠剛と した。この錠片を容器 $(\mathrm{W} 200 \mathrm{~mm} \times \mathrm{L} 200 \mathrm{~mm} \times \mathrm{H} 70 \mathrm{~mm}$ ) の中で, $1 \mathrm{~mm}$ 以下に粒度調整した粉コークス内に充填し,

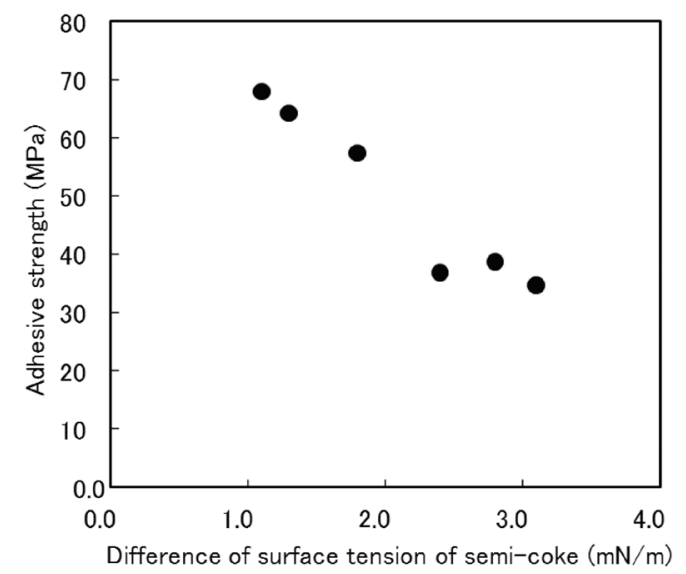

Fig. 4. Relationship between adhesive strength and difference in surface tensions of semi-coke.

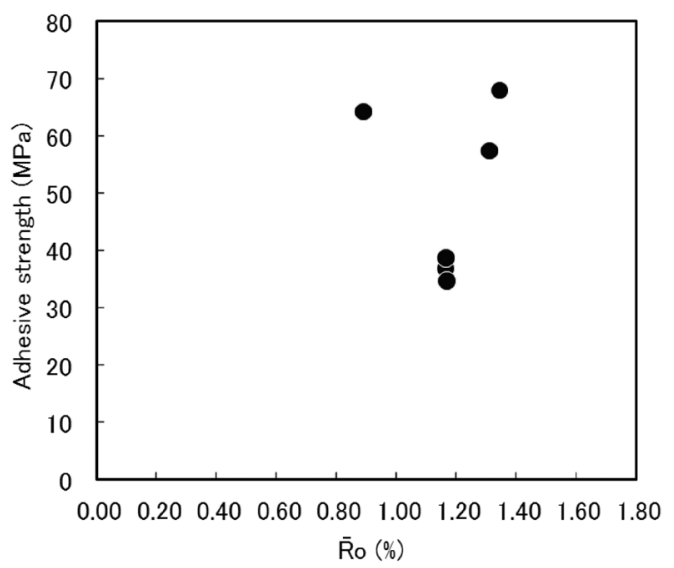

Fig. 5. Relationship between adhesive strength and average $\bar{R} 0$.
窒素雾囲気下で $1000^{\circ} \mathrm{C}$ まで昇温速度 $3^{\circ} \mathrm{C} / \mathrm{min}$ で錠剤の軸方 向に対して上下方向より加熱することで乾留した。その後 冷却し，得られたサンプルを軸方向に切断し，その断面を 顕微鏡で観察した。使用した石炭の性状を Table 3 に, 石炭 の組み合わせと, 組み合わせた石炭のセミコークスの表面 張力差を Table 4 にそれぞれ示す。本実験では, 2層のサン プルの上層の石炭銘柄は Coal Gで同一とし, 下層の石炭銘 柄として表面張力の異なる 2 種類の石炭を選定し, 表面張 力差が異なる 2 種類のサンプルを作製した。

Sample A（上層と下層のセミコークス表面張力差： 1.5 $\mathrm{mN} / \mathrm{m}$ ) と Sample B (上層と下層のセミコークス表面張力 差 : $0.1 \mathrm{mN} / \mathrm{m}$ ) の界面の顕微鏡写真を Fig.9に示す。Sample

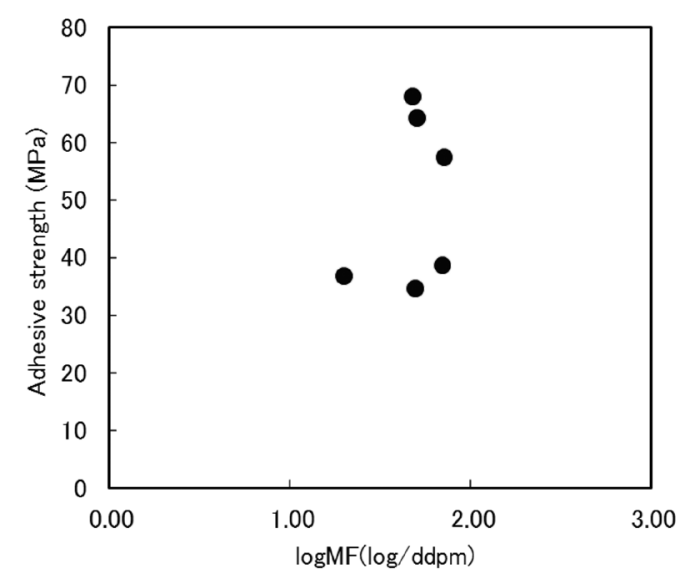

Fig. 6. Relationship between adhesive strength and average $\log \mathrm{MF}$.

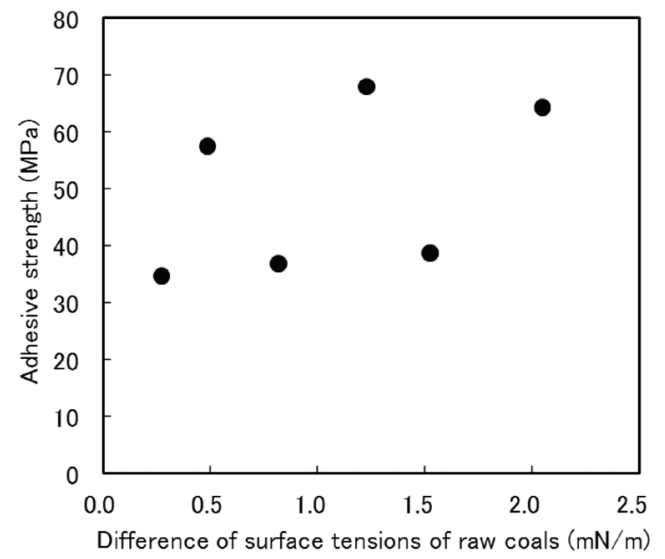

Fig. 7. Relationship between adhesive strength and difference in surface tensions of raw coals.

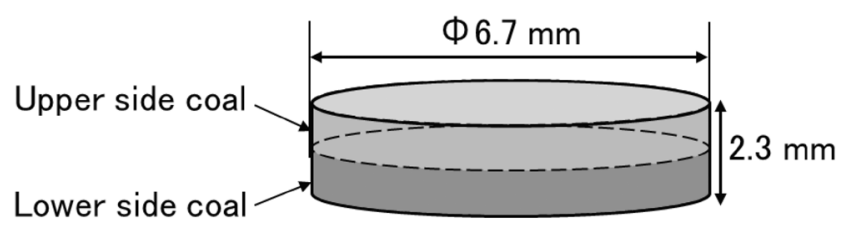

Fig. 8. Schematic illustration of two-layered sample (before carbonization). 
A 中の Coal G は，サンプルの上端周辺と比較して，界面付 近に粗大な気孔を生成していることが確認された。一方 で, Sample B 中の Coal G は比較的均一な気孔構造を形成し ており，粗大な気孔は確認されなかった。これらの結果か ら，表面張力差が大きい石炭同士の場合，気孔の形成や成 長が促進され，接着界面で接着が悪くなることが示唆され る。しかしながら，気孔形成および気孔成長には多くの因 子が影響しており，実験による定量的な評価が困難である ことから, 表面張力と気孔構造の関係については更なる調 査が必要であると考えられる。

Table 3. Coal properties of the components in two-layered sample.

\begin{tabular}{ccccccc}
\hline $\begin{array}{c}\text { Coal } \\
\text { brand }\end{array}$ & $\begin{array}{c}\text { Surface tension } \\
(\mathrm{mN} / \mathrm{m})\end{array}$ & $\begin{array}{c}\overline{\mathrm{R}} \mathrm{c} \\
(\%)\end{array}$ & $\begin{array}{c}\text { logMF } \\
(\mathrm{log} / \mathrm{ddpm})\end{array}$ & $\begin{array}{c}\text { TI } \\
(\%)\end{array}$ & $\begin{array}{c}\text { Ash } \\
(\text { wt \% d.b. })\end{array}$ & $\begin{array}{c}\text { VM } \\
\text { (wt\% d.b.) }\end{array}$ \\
\hline Coal G & 40.9 & 0.73 & 2.37 & 17.5 & 9.0 & 37.3 \\
Coal H & 40.8 & 1.28 & 1.23 & 45.1 & 7.3 & 20.8 \\
Coal I & 38.4 & 1.23 & 0.60 & 42.0 & 8.8 & 21.3 \\
\hline
\end{tabular}

Table 4. Combination of coal brands of the component in twolayered sample and difference in surface tension of semi-coke between the components of the sample.

\begin{tabular}{ccc}
\hline Sample & Sample A & Sample B \\
\hline $\begin{array}{c}\text { Coal brand of the upper side } \\
\text { Coal brand of the lower side }\end{array}$ & Coal G & Coal G \\
Coal I & 0.1 \\
$\begin{array}{c}\text { Difference in surface tension } \\
\text { of semi-coke }(\mathrm{mN} / \mathrm{m})\end{array}$ & 1.5 & 0.1 \\
\hline
\end{tabular}

$3 \cdot 2 \cdot 2$ 多銘柄配合系におけるコークス強度への表面張 力の影響

続いて，多銘柄配合系に打ける，表面張力差がコークス 強度に及ぼす影響を明らかにするために，電気炉を用い て，多銘柄を配合した石炭乾留試験を実施した。

用いた石炭の性状を Table 5 に, 配合構成と配合炭の性状 を Table 6 に示す。ベース配合である Blend 1 は，セミコー クス表面張力が $40.1 \mathrm{mN} / \mathrm{m}$ から $41.4 \mathrm{mN} / \mathrm{m}$ の間の 5 銘柄の 石炭を配合した。Blend 2-7は, 表面張力の異なる Coal Qと Coal C2 のコークス強度への影響を評価するため, 配合炭の 主要な性状である $\mathrm{R} 0, \log \mathrm{MF}, \mathrm{TI}$ がベース配合とほぼ同一 となるように様々な銘柄の石炭を加え，配合炭を調製した。

Table 5. Coal properties used in carbonization tests.

\begin{tabular}{ccccccc}
\hline $\begin{array}{c}\text { Coal } \\
\text { brand }\end{array}$ & $\begin{array}{c}\text { Surface tension } \\
(\mathrm{mN} / \mathrm{m})\end{array}$ & $\begin{array}{c}\overline{\mathrm{R}} \\
(\%)\end{array}$ & $\begin{array}{c}\text { logMF } \\
(\log / \mathrm{ddpm})\end{array}$ & $\begin{array}{c}\text { TI } \\
(\%)\end{array}$ & $\begin{array}{c}\text { Ash } \\
(\text { wt } \% \text { d.b. })\end{array}$ & $\begin{array}{c}\text { VM } \\
(\text { wt \% d.b. })\end{array}$ \\
\hline Coal E2 & 40.6 & 0.75 & 1.82 & 20.9 & 9.0 & 37.7 \\
Coal J & 40.6 & 1.29 & 1.04 & 47.7 & 7.3 & 20.8 \\
Coal K & 39.5 & 1.10 & 2.88 & 35.3 & 8.6 & 27.3 \\
Coal L & 41.4 & 0.65 & 4.11 & 20.9 & 5.4 & 42.4 \\
Coal M & 40.1 & 0.98 & 2.88 & 34.4 & 8.8 & 26.9 \\
Coal N & 40.9 & 0.85 & 3.13 & 24.4 & 8.8 & 34.5 \\
Coal O & 38.9 & 1.06 & 3.21 & 35.4 & 8.5 & 25.1 \\
Coal P & 41.6 & 1.10 & 3.69 & 19.6 & 8.8 & 27.7 \\
Coal Q & 40.1 & 1.07 & 3.18 & 36.1 & 9.2 & 27.0 \\
Coal C2 & 39.4 & 1.10 & 2.03 & 36.3 & 8.7 & 25.5 \\
\hline
\end{tabular}

Table 6. Coal Blending conditions and coke strengths in carbonization tests.

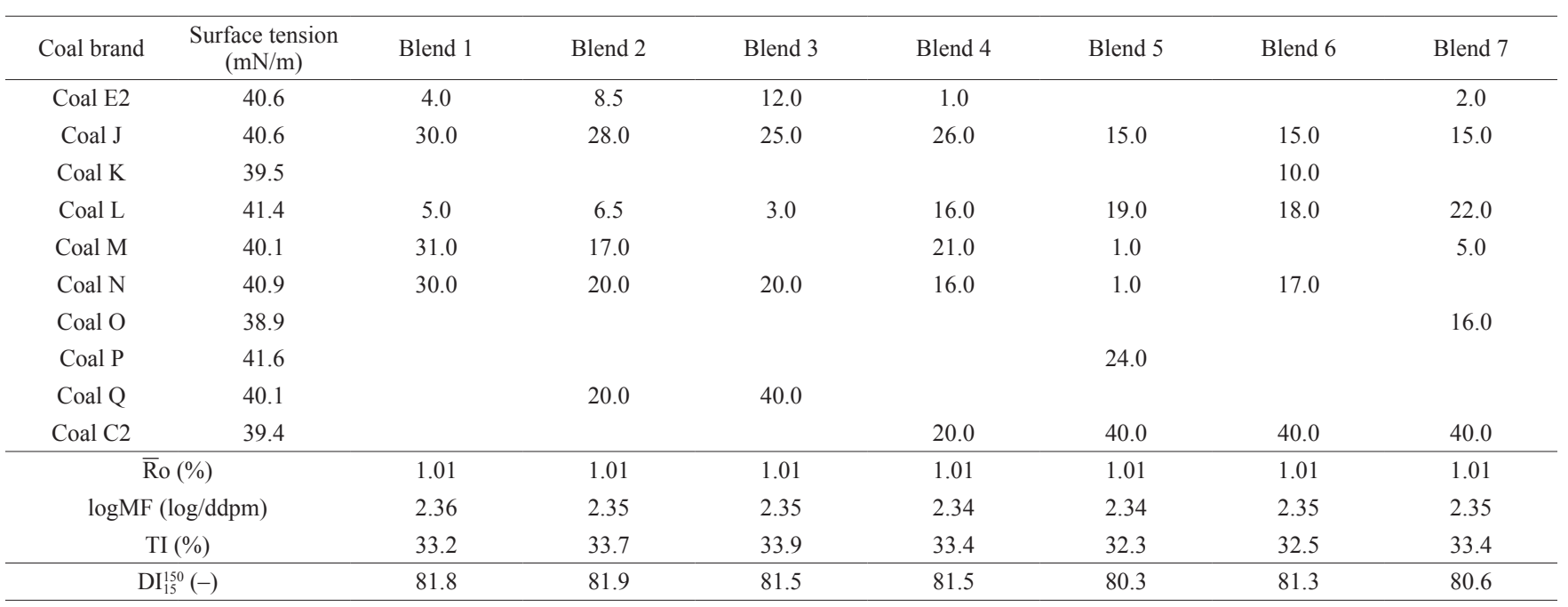

(a)

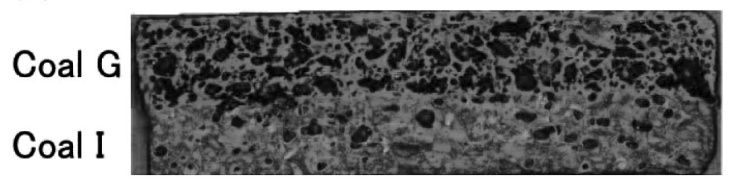

(b)

Coal G

Coal $\mathrm{H}$

$$
\overline{500} \mu \mathrm{m}
$$

Fig. 9. Microscope photographs of two-layered coke structure ((a) Sample A (b) Sample B). 
Coal Q と Coal C2 の配合率とコークス強度の関係を Fig.10に示す。Coal Q を配合した場合, 配合率を増加させ てもコークス強度への影響は確認されなかったが (Blend 2-3), Coal C2 配合した場合は, ベースである Blend 1 と比べ, 配合率の増加に伴ってコークス強度は低下した (Blend 4-7)。特に, Coal C2 $40 \mathrm{wt} \%$ まで増配合すると, コークス強度は大幅に低下した。3・2・1 項の結果では, 配合炭内での銘柄ごとのセミコークス表面張力の差が大き いと,コークス強度が低くなると推察された。Coal Qの七 ミコークス表面張力はべース配合に含まれる石炭の表面張 力の範囲内であったが, Coal C2 はべース配合と比べセミ コークス表面張力が大幅に異なったことが, Coal C2 の配 合率を増加させた際にコークス強度が低下した原因である と考えられる。つまり，配合炭に含まれる石炭のセミコー ク表面張力の範囲を狭めることで, コークス強度を向上さ せることができると推察される。さらに, Blend 5-7の中で Blend 6 最も強度が高いが，これは，Blend 6 の配合炭に 含まれる石炭のセミコークス表面張力の範囲が $39.4 \mathrm{mN} / \mathrm{m}$ (Coal C2) から $41.4 \mathrm{mN} / \mathrm{m}(\mathrm{Coal} \mathrm{L})$ であり，先の差は 2.0 $\mathrm{mN} / \mathrm{m}$ でるが, Blend 5 については $39.4 \mathrm{mN} / \mathrm{m}$ (Coal C2) から $41.6 \mathrm{mN} / \mathrm{m}$ (Coal P) でありその差は $2.2 \mathrm{mN} / \mathrm{m}$, Blend 7

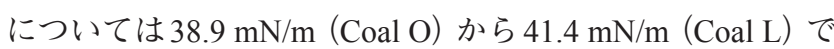
ありその差は $2.5 \mathrm{mN} / \mathrm{m}$ と, Blend 6 が最も配合炭に含まれ る石炭のセミコークス表面張力の範囲が狭かったためであ ると推察される。

さらに, 石炭の組み合わせの観点からは別の示唆が得ら れる。Blend 5 の配合は, ベース配合である Blend 1 に, Coal C2 (表面張力: $39.4 \mathrm{mN} / \mathrm{m}$ ) と Coal P (表面張力: $41.6 \mathrm{mN} / \mathrm{m}$ ) を加えたものである。また，Blend 6は，べース配合に， Coal C2 と Coal K (表面張力 : $39.5 \mathrm{mN} / \mathrm{m}$ ) を加えたもので あり, Blend 7 は, ベース配合に, Coal C2 と Coal O (表面張 力： $38.9 \mathrm{mN} / \mathrm{m}$ ）を加えたものである。それぞれの配合で Coal C2 の配合率は同じ $40 \mathrm{wt} \%$ あ゙るが, Coal C2 と共に

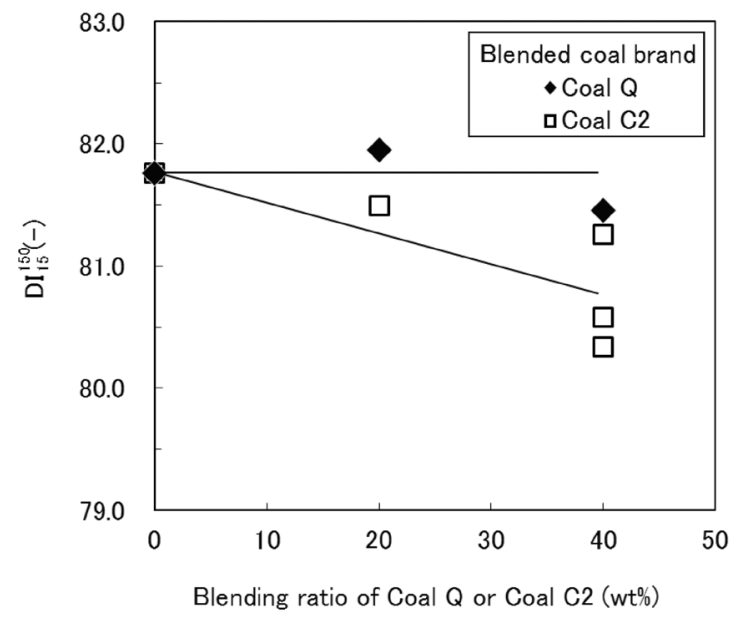

Fig. 10. Relationship between coke strength and blending ratio of Coal Q or Coal C2.
ベース配合に加えた「第2成分」である Coal P, K, Oの表 面張力が異なる。この「第2成分」に着目すると, Blend 6の Coal Kのように，この「第2成分」の表面張力がCoal C2 と ベース配合の間となる場合，コークス強度が最も高くなっ ていることがわかる。一方で, Blend 5 の Coal Pは表面張力 がベース配合よりも高く, Blend 7の Coal Oは Coal C2 より も低いため，これらの「第2成分」はCoal C2を加えたこと による悪影響を軽減することがなかったと考えられる。し たがって，これらの結果は，Coal C2を配合することによる 強度の低下が, Coal C2 の性状のみの影響ではなく, 石炭の 組み合わせにも起因していることを明確に表していると考 えられる。

以上の結果から，セミコークス表面張力の差が大きい場 合にコークス強度が低くなるという, $3 \cdot 2 \cdot 1$ 項で示した ものと同様の傾向が，多銘柄配合系での乾留試験でも確認 することができた。本研究では, 前述のとおり熱処理後, 冷却したセミコークスサンプルを表面張力の測定に使用し ている。この測定值は軟化溶融温度域での軟化溶融物質の 表面張力とは異なる值だと考えられるが, 表面張力はその 物質表面の化学構造と密接な関係があり, 化学反応速度は その反応温度に大きく依存することから, $500^{\circ} \mathrm{C}$ で熱処理 された石炭の化学構造は冷却過程で変化することはほぼな く, 冷却後のセミコークスの化学構造は, 軟化溶融時の石 炭の化学構造をある程度反映させたものになっていると考 えられる。したがって，上述の試験においては，冷却後の セミコークスの表面張力を考虑することの有効性を示す結 果が得られたと考えられる。本節の結果は, 従来の配合指 標を同一としても配合構成によりコークス強度が変化する という石炭の相性の影響の例を示したものであり, 以上の 結果から, 石炭の相性の, 少なくとも一部については, セ ミコークスの表面張力を用いることで予測が可能になると 考えられる。

\section{$3 \cdot 3$ 表面張力の影響の一般化と新配合指標「熱処理配合 炭界面張力」の提案}

これまでの結果で, 配合炭内の石炭を乾留して得られた セミコークスの表面張力, 特に銘柄間の表面張力差とその 石炭の配合量がコークス強度に影響を及ぼしていることが 確認された。しかしながら, この知見を実際のコークス操 業で利用するためには，この配合技術を一般化し，新しい 配合指標として確立する必要がある。筆者らはこの目的を 達成するため, 新しい配合指標である「熱処理配合炭界面 張力」を提案する。

界面張力は, 互いに接触した物質の表面張力から計算 可能である。異なる物質である物質 1 と物質 2 間の界面 張力 $\gamma_{12}$ は物質 1 と物質 2 の表面張力から, Girifalco-Good equation $^{12)}$ により表される式 (1) を用いて導出できる。

$$
\gamma_{12}=\gamma_{1}+\gamma_{2}-2 \phi \sqrt{\gamma_{1} \gamma_{2}}
$$


ここで， $\gamma_{1}$ および $\gamma_{2}$ はそれぞれ，物質 1 ，物質 2 の表面張力

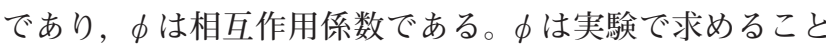
ができ，物質 $1 ， 2$ により異なることが知られている。さら に, D.Li とA.W.Neumannは， $\phi$ の值が $\gamma_{1}, \gamma_{2}$ の值が離れる ほど大きくなると仮定し，式（1）を拡張した式（2）を提案 している ${ }^{13)}$ 。

$$
\gamma_{12}=\gamma_{1}+\gamma_{2}-2 \exp \left[-\beta\left(\gamma_{1}-\gamma_{2}\right)^{2}\right] \sqrt{\gamma_{1} \gamma_{2}}
$$

$\beta$ は実験により決定される定数であり, D.Li と A.W.Neumann は $0.0001247\left(\mathrm{~m}^{2} / \mathrm{mJ}\right)^{2}$ と計算している ${ }^{13)}$ 。本 研究では測定したセミコークスの表面張力を用いて，接触 した2つの石炭粒子界面での界面張力を式 (2) により計算 した。そして，熱処理配合炭界面張力を，式 (3) により計 算される界面での界面張力とその界面の存在確率の積の総 和と定義した。

$$
\gamma_{\text {inter }}=\sum_{i=1}^{n} \sum_{j=1}^{n} w_{i} w_{j} \gamma_{i j}
$$

ここで， $\gamma_{\text {inter }}$ は熱処理配合炭界面張力であり， $\mathrm{w}_{\mathrm{i}}$ は石炭 $\mathrm{i}$ の配合率である $(\mathrm{i}=1,2, \cdots, \mathrm{i}, \cdots \mathrm{n})$ 。

熱処理配合炭界面張力のコークス強度への影響を検証す るため, $3 \cdot 2 \cdot 2$ 項の乾留試験にて使用した配合炭の熱処 理配合炭界面張力を計算した值を Table 7 に示す。

熱処理配合炭界面張力とコークス強度の関係を Fig.11に 示す。熱処理配合炭界面張力の減少に伴い，コークス強度 が向上した。この結果は，他の石炭と表面張力の值が異な る石炭を配合したとしても，熱処理配合炭界面張力を減少

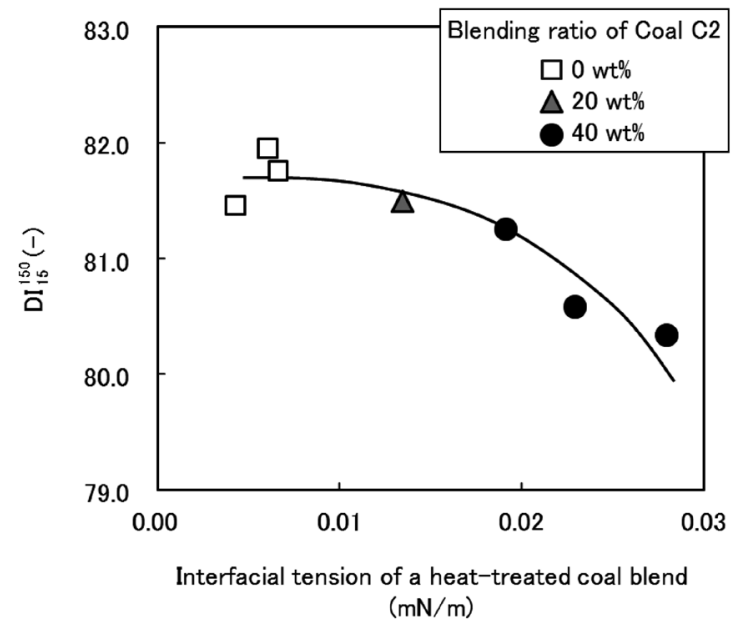

Fig. 11. Relationship between coke strength and interfacial tension of a heat-treated coal blend.
させることでコークス強度が向上することを意味してい る。それぞれの石炭の表面張力と配合率の両方を考慮した 熱処理配合炭界面張力を用いることで, Blend 1-7の違いが 明確に説明可能となったことから，熱処理配合炭界面張力 の配合指標としての有効性を確認することができた。

\section{4. 熱処理配合炭界面張力の実炉適用試験}

熱処理配合炭界面張力がコークス強度に及ぼす影響を実 炉スケールで検証するため, 福山5コークス炉で, 熱処理 配合炭界面張力がコークス強度に及ぼす影響の調査を行っ た。

コークス強度, $\overline{\mathrm{R}} \mathrm{o}, \log \mathrm{MF}$ ，および熱処理配合炭界面張 力の推移を Fig. 12 に示す。熱処理配合炭界面張力が 0.017 $\mathrm{mN} / \mathrm{m}$ 以下の期間 (1-8 日目) のコークス強度の平均值は 84.7 であった。一方, 熱処理配合炭界面張力が $0.017 \mathrm{mN} / \mathrm{m}$ 以上の期間 (9-15日目) のコークス強度の平均值は84.2で あった。両側 $95 \%$ の信頼区間を用いた 2 水準間の $\mathrm{t}$ 検定の 結果，この差は統計的に有意であった。この結果から，実 操業においても界面張力がコークス強度の配合指標とし て有効であることが確認された。さらに，以上の結果から， 熱処理配合炭界面張力を最小化することでコークス強度が 向上することが明らかとなり, 熱処理配合炭界面張力を適 正な範囲に調整することで，より安定した高強度コークス の製造が可能になると考えられる。
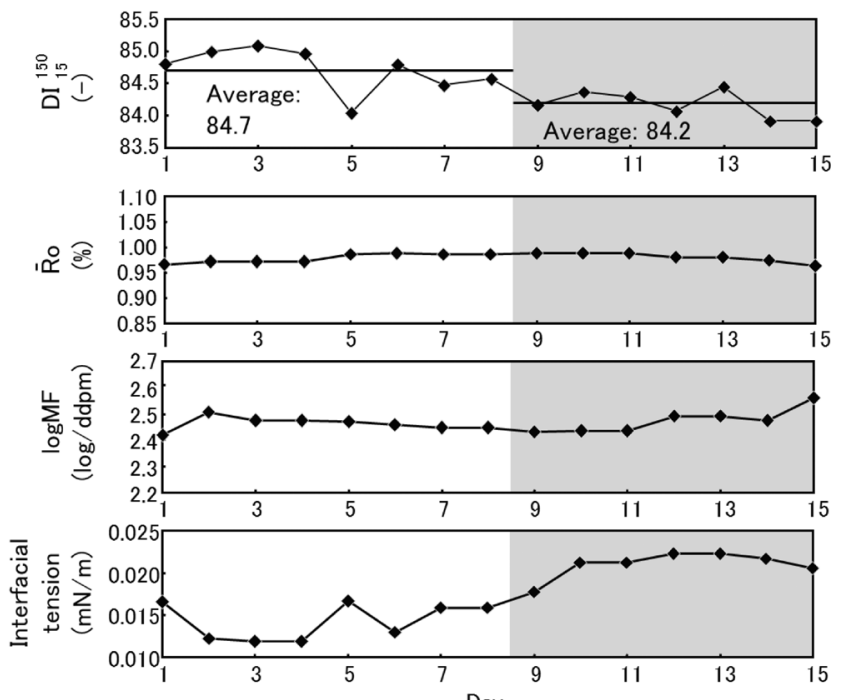

Day

Fig. 12. Variations of coke strength with changing interfacial tension of coal blend at the commercial plant.

\begin{tabular}{|c|c|c|c|c|c|c|c|}
\hline Coal blend & Blend 1 & Blend 2 & Blend 3 & Blend 4 & Blend 5 & Blend 6 & Blend 7 \\
\hline Interfacial tension $(\mathrm{mN} / \mathrm{m})$ & 0.007 & 0.006 & 0.004 & 0.013 & 0.028 & 0.019 & 0.023 \\
\hline
\end{tabular}

Table 7. Calculated interfacial tensions of heat-treated coal blends used in carbonization tests. 


\section{5. 結言}

石炭の相性に着目し，基礎研究を実施した結果，以下の 知見を得た。

（1）コークス強度に及ぼす石炭の相性の影響は，少なくと もその一部は石炭粒子間の接着強度で説明することが できることを示した。

（2）石炭を $500^{\circ} \mathrm{C}$ で熱処理して得られたセミコークスの表 面張力により, 石炭粒子間の接着強度が推定可能であ り，この表面張力の差がこれまで相性の影響といわれ ていたコークス強度低下の原因となりうることを明ら かにした。

（3）各石炭の表面張力と配合率より計算される「熱処理配 合炭界面張力」により, 配合炭中の石炭銘柄の相性が 及ぼすコークス強度への影響が評価できることを明確 化した。

以上の知見により, コークス操業において, 以下の 2 点 が実現可能であることが示唆される。

(1) 熱処理配合炭界面張力を調整することで, 石炭の相性 に起因するコークス強度の予期せぬ低下を回避するこ
とができる。

（2）相性の良い銘柄同士を組み合わせて配合炭を調製する ことで，原料炭資源を有効活用することができる。

\section{文献}

1 ) K.Matsubara, T.Miyazu and R.Takahashi: Comun. Serv. Geol. Port., 70(1984), No.2, 161.

2 ) T.Miyazu, S.Itagaki and S.Mitani: Proc. 1st Int. Meeting of Coal and Coke Applied to Ironmaking, Brazilian Society for Metals, Brazil, (1987), 1

3 ) T.Miyazu: Engineers, 559(1995), 8.

4 ) T.Miyazu, Y.Okuyama, N.Suzuki, T.Fukuyama and T.Mori: Nippon Kokan Tech. Rep. Overseas, 67(1975), 1.

5 ) S.Sakamoto and K.Igawa: Tetsu-to-Hagané, 87(2001), 238.

6 ) K.Nishioka and S.Yoshida: Tetsu-to-Hagané, 70(1984), 351.

7 ) T.Aramaki, Y.Miura, M.Sakawa and Y.Sakurai: J. Fuel Soc. Jpn., 69(1990), 355

8 ) N.S.Gryaznov and L.V.Kopeliovich: Koks I Khimiya, 7(1975), 2.

9 ) H.Suginobe and T.Miyagawa: Coke Circ., 29(1980), 159.

10) K.L.Mittal: Polym. Eng. Sci., 17(1977), 467.

11) M.C.Williams and D.W.Fuerstenau: Int. J. Miner. Process., 20(1987), 153.

12) J.Girifalco and R.J.Good: J. Phys. Chem., 61(1957), 904

13) D.Li and A.W.Neumann: J. Colloid Interf. Sci., 148(1992), 190. 